\title{
COMPARATIVE STUDY OF ANTIMICROBIAL ACTIVITY OF LEMONGRASS (CYMBOPOGON CITRATUS), CLOVE (SYZYGIUM AROMATICUM), AND TULSI (OCIMUM) ESSENTIAL OILS AGAINST FOODBORNE PATHOGENS
}

\author{
MONIKA YADAV, ROOPAL DHAR, SOHINI SINGH, TANU ALLEN* \\ Department of Amity Institute of Biotechnology, Amity University, Noida, Uttar Pradesh, India. Email: tallen@amity.edu \\ Received: 22 September 2018, Revised and Accepted: 16 January 2019
}

\begin{abstract}
Objective: The present work aims to compare the essential oils (EOs) of Lemongrass (Cymbopogon citratus), Clove (Syzygium aromaticum), and Tulsi (Ocimum sp.) having antimicrobial activity and to find the most effective EO against different types of foodborne microorganisms.

Methods: The EOs were investigated for its antimicrobial activity against different types of Gram-negative and Gram-positive bacteria such as Escherichia coli, Micrococcus luteus, Staphylococcus aureus, and Bacillus cereus and fungal strains such as Aspergillus niger, Candida albicans, Chaetomium globosum, and Penicillium funiculosum by agar well diffusion method. The antimicrobial actions of these EOs were evaluated by calculating the zone of inhibition.

Results: Of the three EOs used in the study, the effect of clove oil was found greater against all the microorganisms followed by lemongrass and tulsi EOs. All the microorganisms used in the study were found sensitive to clove EO, wherein the highest zone of inhibition was observed

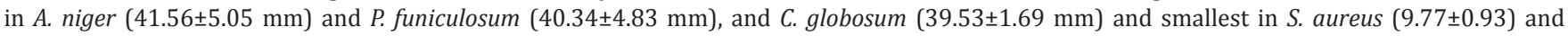
E. coli 1(11.07 \pm 0.52$)$. Moreover, it was also found that EOs exhibit more sensitivity toward Gram-positive bacteria than Gram-negative bacteria.

Conclusion: The successful effectiveness of EO can play an important role in resolving the major problem of human health arising due to the use of chemical preservative. It was found that EO of clove oil was the most effective against fungal and bacterial strains than lemongrass and tulsi EOs. Furthermore, clove oil is less costly than lemongrass and tulsi oil; it can be more economic and promising to be used as a food preservative against foodborne pathogens.
\end{abstract}

Keywords: Essential oils, Antimicrobial activity, Agar well diffusion, Food preservatives.

(C) 2019 The Authors. Published by Innovare Academic Sciences Pvt Ltd. This is an open access article under the CC BY license (http://creativecommons. org/licenses/by/4. 0/) DOI: http://dx.doi.org/10.22159/ajpcr.2019.v12i4.29451

\section{INTRODUCTION}

Food preservatives are the compounds which are being tremendously used for increasing the lifespan of food, by preventing decomposition caused by the growth of microorganisms and maintaining the quality and integrity of food [1]. From the past few decades, the synthetic chemical compounds such as sodium benzoate, benzoic acid, sodium sorbate, potassium sorbate, and sodium nitrite and nuclear radiations are being used by food industries as preservatives. These have proved to be very efficacious in increasing the shelf life by preventing or delaying the growth of bacteria, molds, insects, and other harmful microorganisms. Synthetic compounds and radiations which are being used to preserve food are not only making foods toxic and radioactive but are also causing changes in the quality of food, color, taste, and texture [2] and cause severe harmful effects such as headache, palpitations, allergies, stomach cancer, skin rashes, and asthma [2,3]. The symptoms of disease or allergy can be simply noticed after consuming these foods, but some people develop these symptoms after certain period of time, so it becomes hard to know the cause of problem. Harmful effects arising from tremendous use of synthetic compounds have encouraged the idea of replacing the chemical additives with essential oils (EOs) having natural antimicrobial properties, antioxidant properties, and their application in food preservation.

EOs extracted from plants are volatile and aromatic liquids [4-6]. The chemical compositions of EOs play a significant role in antimicrobial properties and it depends on their content, concentration, and interactions between the main active compounds. Chemical compounds such as eugenol, thymol, linalool, sesquiterpenes, cymene, terpenoids, monoterpenes, and specially geranial [7] or their oxygenated derivatives present in plant-derived EOs can easily pass across the cell membrane to bring biological reactions $[8,9]$. There are numbers of EOs of medicinal and herbal plants which can be used as food preservative such as tea tree, thyme, lemongrass, oregano, rosemary, calamint, clove, tulsi or lavender, and many others [10].

Ocimum tenuiflorum or Ocimum sanctum (Tulsi) is commonly known as "Queen of plants" and the "mother medicine of nature" due to its unique antimicrobial properties. Tulsi EO and their principal constituents thymol (53.2\%), $\gamma$-terpinene (25.7\%), eugenol (12.7\%), and $p$-cymene $(7.3 \%)$ are known to exhibit properties such as antimicrobial, antioxidants, analgesics, stress reducers, inflammation reliever, antiasthmatic, hypotensive, and immune modulatory agents [11].

Clove (Syzygium aromaticum) is found to be one of the richest sources of phenolic compounds such as eugenol (76.8\%), $\beta$-caryophyllene (17.4\%), $\alpha$-humulene (2.1\%), and eugenyl acetate $(1.2 \%)$ and possesses great potential for pharmaceutical, antioxidant, and antimicrobial activity. These properties are found much higher in clove than in fruits, vegetables, and other spices so it should deserve special attention [12].

Cymbopogon citratus, commonly known as lemongrass, is herbal plant which belongs to the grass family of Poaceae. The major constituents of EO from this which is responsible for its antimicrobial activity are geranial $(45.7 \%)$, myrcene $(3.9 \%)$, and 6-methylhept-5en-2-one $(2.7 \%)$. The lemongrass is more efficacious as compare to penicillin and its effectiveness is due to its bacterial and antifungal properties [13]. 
As no previous comparative study of EOs (lemongrass, clove, and tulsi) against all the selected pathogens has been carried out; therefore, the study is novel. The objective of this research paper is to perform a comparative study of the antimicrobial activity of lemongrass, clove, and tulsi (EOs) oils against nine different types of foodborne pathogens (bacterial and fungi) and to find the most effective EO against these microorganisms.

\section{METHODS}

The present study was conducted to investigate the activity of lemongrass, clove, and tulsi oil against various selected foodborne microorganisms.

\section{Procurement of chemicals}

The EO of lemongrass, clove, and tulsi was procured from SigmaAldrich, India.

\section{Bacterial and fungal strains}

The standard strains of pathogens were purchased from National Collection of Industrial Microorganisms, Pune. Two strains of Gramnegative bacteria, namely Escherichia coli 1 (ATCC No-8739) and E. coli 2 (ATCC No-10536), and three strains of Gram-positive bacteria, namely; Micrococcus luteus (ATCC No-9341), Bacillus cereus (ATCC No11778), and Staphylococcus aureus (ATCC No-29737), and against four strains of fungus, namely Candida albicans (ATCC No-3471), Aspergillus niger (ATCC No-16404), Penicillium funiculosum (ATCC No-11797), and Chaetomium globosum (ATCC No-6205).

\section{Preparation of inoculum}

Nutrient agar slants were used to streak the bacteria followed by incubation overnight at $37^{\circ} \mathrm{C}$, whereas Chloramphenicol Yeast Glucose Agar slants were used to streak the fungus followed by incubation for 5 days at $22^{\circ} \mathrm{C}$.

\section{Preparation of EOs}

About $30 \%$ of concentrations (v/v) of EO were prepared aseptically using sterile Tween-80.

\section{Antibacterial activity}

The activities of bacterial and fungal cultures for the inhibitory effect of EO for $30 \%$ concentration were performed using agar well diffusion method [14].

\section{Agar well diffusion assay (inhibition of zone evaluation)}

Antimicrobial activity and resistance were estimated using agar well diffusion assay method. 0.5 McFarland density of bacterial and 0.8 McFarland density of fungal culture were adjusted to $1.0 \times 10^{8} \mathrm{CFU} / \mathrm{ml}$ using normal saline $(0.85 \% \mathrm{NaCl})$ and Densitometer (Biosan) instrument. $100 \mu \mathrm{l}$ of each adjusted cultures were added to individual molten cool MHA (Mueller-Hinton agar), sterile Petri plates and these plates were allowed to solidify. Sterile cork was used to punch $6 \mathrm{~mm}$ diameter wells at different places of plates. About $100 \mu \mathrm{l}$ of all EOs were added into the wells of assay plates. Plates with bacterial growth were kept for incubation at $37^{\circ} \mathrm{C}$ overnight whereas with fungal growth were kept for incubation at $22^{\circ} \mathrm{C}$ for 5 days. After incubation, Vernier caliper was used to measure the diameters of zone of inhibition observed on the Petri plates.

\section{Statistical analysis}

The experimentations were performed in quadruplicate and the results were depicted in mean \pm standard deviation for each microorganism in the tables and mean \pm standard error in the graph using the SPSS software.

\section{RESULTS}

In this study, EOs were tested against different foodborne microorganisms containing both Gram-positive bacteria and Gramnegative bacteria and fungi. The mechanism of the chemical composition of EOs and their components can have a single target or multiple targets of their activity. All the selected microorganisms exhibited difference in their sensitivity against different EOs when tested by agar well diffusion assay (Table 1).

The diameter of the zones of inhibition varied depending on EOs (30\%) and bacterial or fungal species used. The strongest inhibition activity of lemongrass EO was observed against A. niger $(50.15 \pm 0.82 \mathrm{~mm})$, C. albicans $(37.17 \pm 2.03 \mathrm{~mm})$, C. globosum $(34.73 \pm 1.21 \mathrm{~mm})$, and M. luteus (20.47 $\pm 1.47 \mathrm{~mm}$ ) (Table 1), (Figs. 1 and 2) as compared to clove and tulsi oils tested. Clove oil showed higher activity against A. niger $(41.56 \pm 5.05 \mathrm{~mm})$, P. funiculosum $(40.34 \pm 4.83 \mathrm{~mm})$, and C. globosum $(39.53 \pm 1.69 \mathrm{~mm})$, respectively, compared to other oils (Fig. 1). Similar greater zone of inhibition was observed in P. funiculosum $(21.17 \pm 1.37 \mathrm{~mm})$, A. niger $(19.26 \pm 1.78 \mathrm{~mm})$, and C. globosum (18.62 $\pm 0.37 \mathrm{~mm}$ ) against tulsi oil (Fig. 1). Clove and tulsi oil showed shorter zones of inhibition against $S$. aureus $(9.77 \pm 0.93 \mathrm{~mm})$, respectively (Fig. 2), when compared to other bacterial isolates. Clove $(11.07 \pm 0.52 \mathrm{~mm})$ and tulsi $(14.26 \pm 0.82 \mathrm{~mm})$ oils produced smaller sizes of zones against $E$. coli 1 (Fig. 3) relative to other bacteria studied. Tulsi oil showed no zone of inhibition against $M$. luteus as compared to lemongrass $(20.47 \pm 1.47 \mathrm{~mm})$ and clove oils $(14.55 \pm 4.60 \mathrm{~mm})$. Similarly, no zone of inhibition was measured in B. cereus isolate against tulsi oil whereas against lemongrass $(19.41 \pm 1.03 \mathrm{~mm})$ and clove oil $(13.86 \pm 1.19 \mathrm{~mm})$, smaller zone size was observed. In E. coli 2 isolate, zone of inhibition was observed only against clove oil $(12.8 \pm 2.05 \mathrm{~mm})$. Results of the antimicrobial action of EOs by agar well diffusion method exhibited that Gram-positive bacteria are much sensitive against the EOs than Gram-negative bacteria (Table 1).

A. niger was found to be more sensitive to lemongrass followed by clove and tulsi oils used in this experiment. Hammer [5] reported similar antimicrobial activity of EOs. In this study, clove and lemongrass oils were found most microfungicidal against $C$. globosum species. The antimicrobial activity of lemongrass has also been reported against Cymbopogon citrates [14] and their large percentage of citral (3,7-dimethyl-2,6-octadienal) constituent [15-17]. The lemongrass oil can easily attach and penetrate to the cell wall of pathogens and cause cell lysis due to the presence of high lipophilicity and volatility [18]. Several studies have revealed the antimicrobial effects of clove oil $[19,20]$. Clove oil inhibits the activity of pathogens due to the presence of several main active constituents such as eugenol, eugenyl acetate, betacaryophyllene, and 2-heptanone [21]. All the microorganisms used in the study, namely A. niger, C. albicans, C. globosum, M. luteus, S. aureus, B. cereus, P. funiculosum, E. coli 1 , and E. coli 2 were found sensitive

Table 1: Antimicrobial activity of EOs against various foodborne microorganisms

\begin{tabular}{llll}
\hline \multicolumn{2}{l}{ Zone of inhibition (mean \pm SD) } & & \\
\hline $\begin{array}{l}\text { Name of } \\
\text { microorganisms }\end{array}$ & Lemongrass & Clove & Tulsi \\
\hline $\begin{array}{lll}\text { Gram-negative bacteria } \\
\text { E. coli } 1\end{array}$ & $13.88 \pm 1.32$ & $11.07 \pm 0.52$ & $14.26 \pm 0.82$ \\
$\quad$ E. coli 2 & 0 & $12.8 \pm 2.05$ & 0 \\
Gram-positive bacteria & & & \\
M. luteus & $20.47 \pm 1.47$ & $14.55 \pm 4.60$ & 0 \\
$\quad$ B. cereus & $19.41 \pm 1.03$ & $13.86 \pm 1.19$ & 0 \\
S. aureus & $19.56 \pm 5.83$ & $9.77 \pm 0.93$ & $9.25 \pm 0.67$ \\
Fungi & & & \\
A. niger & $50.15 \pm 0.82$ & $41.56 \pm 5.05$ & $19.26 \pm 1.78$ \\
C. albicans & $37.17 \pm 2.03$ & $18.16 \pm 1.27$ & $10.66 \pm 0.68$ \\
C. globosum & $34.73 \pm 1.21$ & $39.53 \pm 1.69$ & $18.62 \pm 0.37$ \\
P. funiculosum & $15.17 \pm 1.01$ & $40.34 \pm 4.83$ & $21.17 \pm 1.37$ \\
\hline
\end{tabular}

$\mathrm{n}=4$, Zone of inhibition (mean \pm SD). EOs: Essential oils, SD: Standard deviation, E. coli: Escherichia coli, M. luteus: Micrococcus luteus, B. cereus: Bacillus cereus,

S. aureus: Staphylococcus aureus, A. niger: Aspergillus niger, C. albicans: Candida albicans, C. globosum: Chaetomium globosum, P. funiculosum: Penicillium funiculosum 


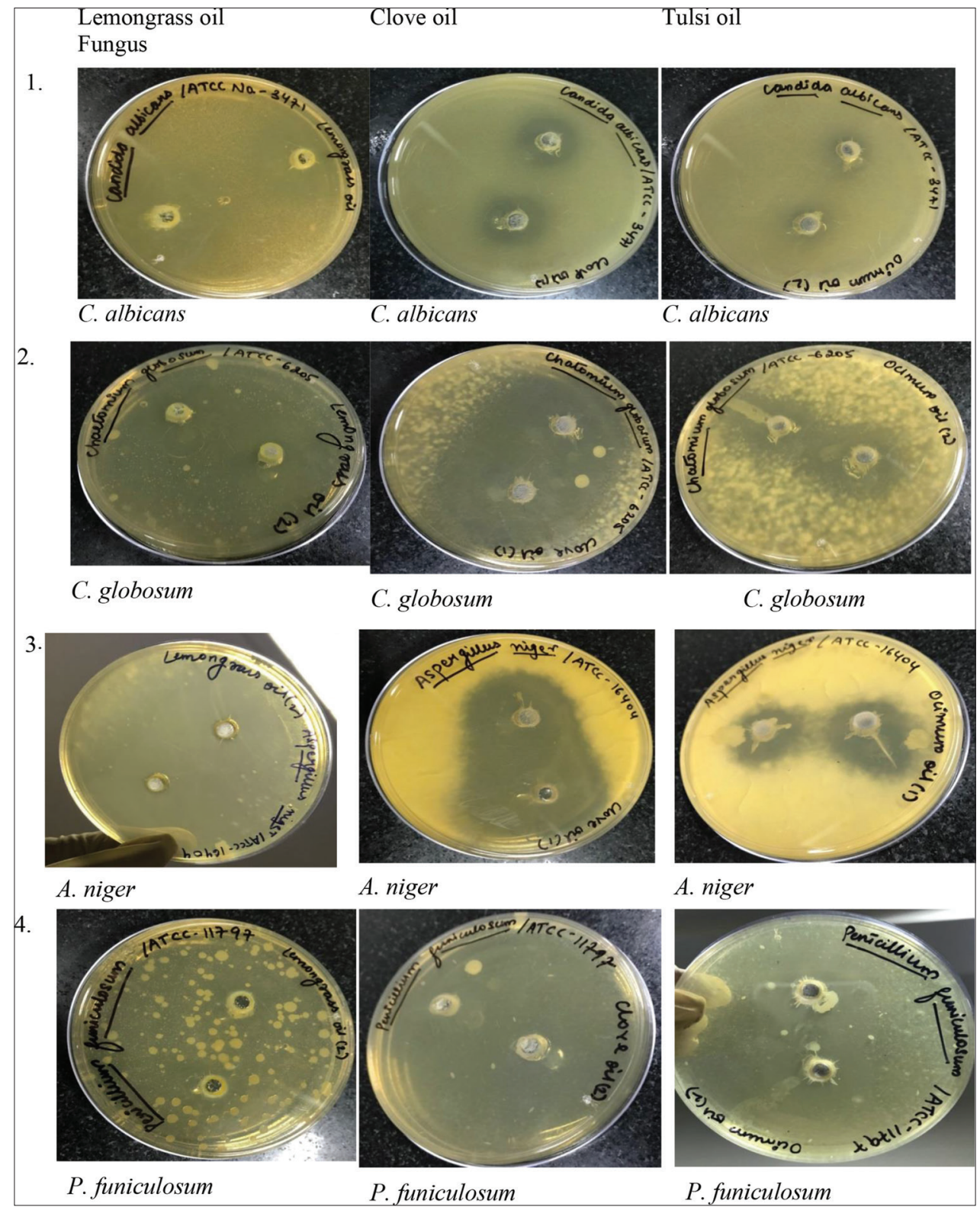

Fig. 1: Zone of inhibition of fungus against different essential oils

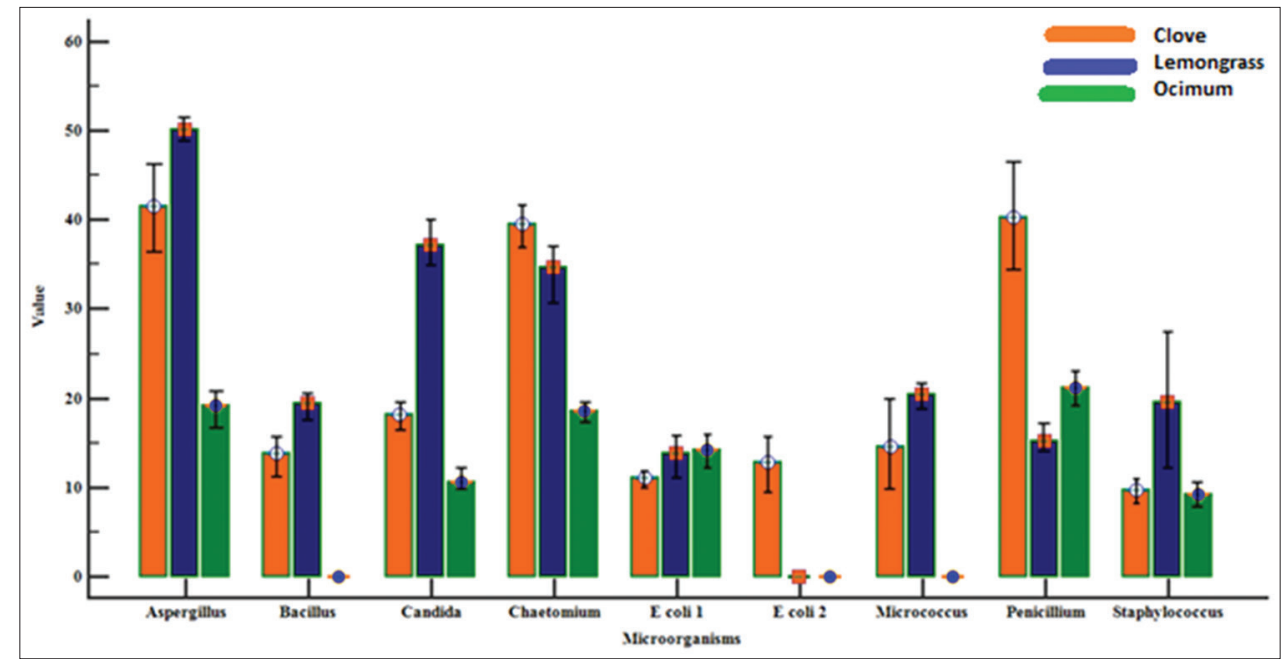

Graph 1: Comparison between the zones of inhibition of essential oils against all test microorganisms as mean \pm standard error. $x$ (axis) $=$ Name of microorganisms, $y$ (axis) = Zone of inhibition (in $\mathrm{mm}$ ) 


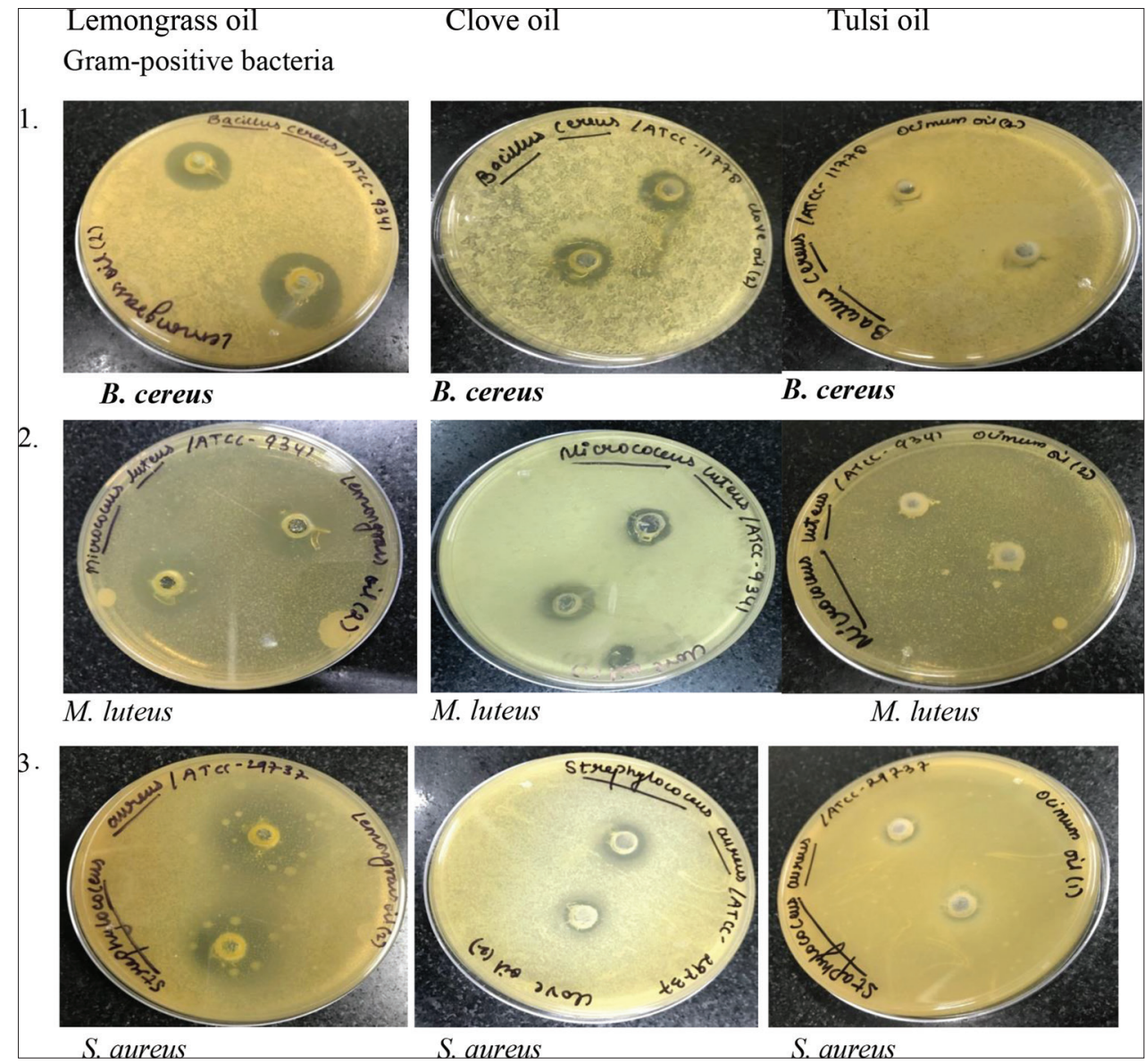

Fig. 2: Zone of inhibition of Gram-positive bacteria against different essential oils

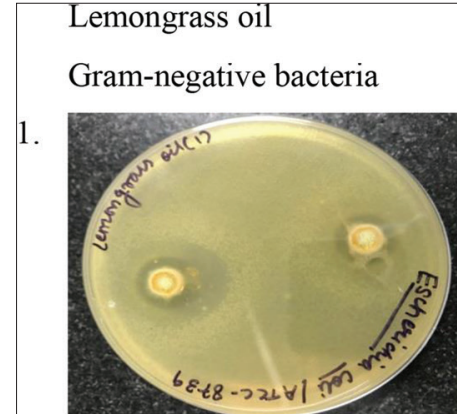

E. $\operatorname{coli} 1$

2.

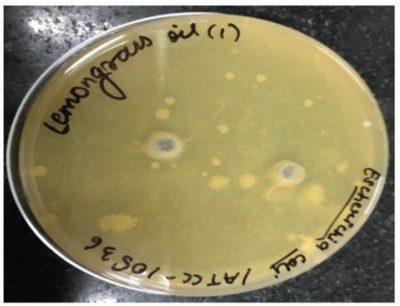

E. coli 2
Clove oil

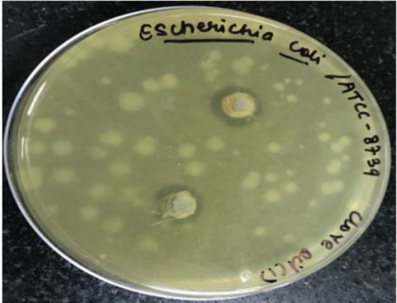

E. coli 1

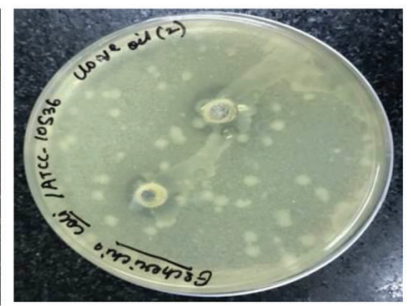

E. coli 2

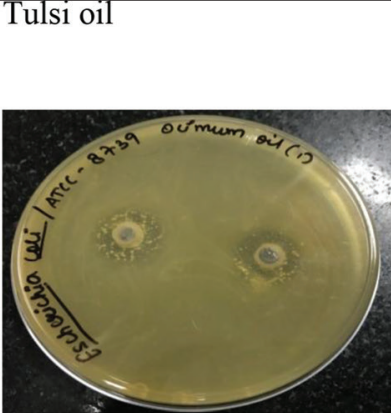

E. coli 1

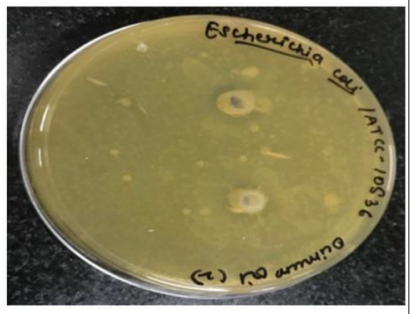

E. coli 2

Fig. 3: Zone of inhibition of Gram-negative bacteria against different essential oils

to clove EO, wherein the highest zone of inhibition was observed in A. niger, C. globosum, and P. funiculosum and the smallest zone size was observed in S. aureus and E. coli 1 (Graph 1).

Mishra reported the antibacterial activity of tulsi oil against Grampositive and Gram-negative bacteria [22]. Our results exhibit fungistatic activity of tulsi oil against $P$. funiculosum, A. niger, and C. globosum.
However, less or no activity was observed against $S$. aureus, M. luteus, B. cereus, and E. coli 2 (Graph 1).

\section{DISCUSSION}

Some EOs exhibit distinct activity in inhibiting the mycelia growth [23]. Tyagi and Malik [24] have reported in their study that fungal cells lose their original shape and appeared shrunken and partially deformed. 
Several investigators have reported that EOs affect and damage bacterial cell membrane [25-27]. Moreover, EOs exhibit more sensitivity toward Gram-positive bacteria than Gram-negative bacteria [26]. This might be attributed to the inflexible, complex and lipopolysaccharide (LPS)-rich external layer of Gram-negative bacteria, which inhibits passage of hydrophobic compounds through its membrane, unlike Gram-positive bacteria which have thick peptidoglycan wall that is inefficient to prohibit the passage of small antimicrobial molecules through it [28-30]. In addition, Gram-positive bacteria may facilitate the passage of hydrophobic compounds of EOs due to the lipophilic ends of lipoteichoic acid present in the cell membrane. The comparative study of the effectiveness of EOs (lemongrass, clove, and tulsi) in the present work on the various test microorganisms suggests them as an efficacious antimicrobial agent where strong inhibition activity was found against fungal strains than bacterial (Gram-positive and -negative) strains (Fig. 2). Furthermore, of the three EOs used in the study, effect or sensitivity of clove oil was found greatest against all the microorganisms followed by lemongrass and tulsi EOs.

\section{CONCLUSION}

All EOs included in this study possess good antimicrobial activity and can thus be consumed in context of the health benefit as they inhibit the growth against common foodborne pathogens. It was found that EO of clove oil was the most effective against fungal and bacterial strains than lemongrass and tulsi EOs. Furthermore, clove oil is less costly than lemongrass and tulsi oil; it can be more economic and promising to be used as a food preservative against foodborne pathogens.

\section{AUTHORS' CONTRIBUTIONS}

Monika and Dr. Tanu conceived the present idea. Dr. Tanu and Dr. Sohini encouraged Monika and Roopal to investigate and supervised the findings of this work. All authors discussed the results and contributed to the final manuscript.

\section{CONFLICTS OF INTEREST}

Declared none.

\section{REFERENCES}

1. Winter R. A Consumer's Dictionary of Food Additives. New York: Three River Press; 1994. p. 112.

2. John EM. Ionizing radiations sources. Biol Eff Emission Expo 2003;83:1766.

3. Kinderler JL, Hatton PV. Fungal metabolites of sorbic acid. Food Addit Contam 1990;7:657-69.

4. Deans SG, Ritchie G. Antibacterial properties of plant essential oils. Int J Food Microbiol 1987;5:165-80.

5. Hammer KA, Carson CF, Riley TV. Antimicrobial activity of essential oils and other plant extracts. J Appl Microbiol 1999;86:985-90.

6. Sánchez E, García S, Heredia N. Extracts of edible and medicinal plants damage membranes of vibrio cholerae. Appl Environ Microbiol 2010;76:6888-94.

7. Madan KA, Devaki T. Geraniol, a component of plant essential oils-a review of its pharmacological activities. Int J Pharm Pharm Sci 2015;7:67-70

8. Lin KH, Lin MY, Shih MC, Yang K, Hwang SY. Major chemotypes and antioxidative activity of the leaf essential oils of Cinnamomum osmophloeum Kaneh from a clonal orchard. Food Chem 2007; 105:133-9.

9. Cunha JA, Bolzan PL, Fausto PV, Scheid AC, Madalosso RG, Heinzmann MB, et al. Characterization and antifungal activity of the essential oil of Tagetes minuta front of the Cryptococcus Spp. Isolates from the environment. Int J Pharm Pharm Sci 2016;8:390-2.
10. Ebrahimi M, Darani K. Essential oils as natural food preservatives: Antimicrobial and antioxidant applications.In: Antimicrobials from Nature:Effective Control Agents for Drug Resistant Pathogens.Vol. 1: Transworld Research Network; 2013. p. 15-37.

11. Pattanayak P, Behera P, Das D, Panda SK. Ocimum sanctum Linn. A reservoir plant for therapeutic applications: An overview. Pharmacogn Rev 2010;4:95-105.

12. Shan B, Cai YZ, Sun M, Corke H. Antioxidant capacity of 26 spice extracts and characterization of their phenolic constituents. J Agric Food Chem 2005;53:7749-59.

13. Lutterodt GD, Ismail A, Basheer RH, Baharudin HM. Antimicrobial effects of Psidium guajava extract as one mechanism of its antidiarrhoeal action. Malays J Med Sci 1999;6:17-20.

14. Southwell A, Hayes A, Markherm J, Leach D. The search for optimally bioactive Australian tea tree oil. Acta Hortic 1993;334:256-65.

15. Ganjewala D. Cymbopogon essential oils-chemical compositions and bioactivities. Int J Essen Oil Ther 2009;3:56-65.

16. Ganjewala D, Gupta AK, Muhury R. An update on bioactive potential of a monoterpene aldehyde citral. J Biol Active Prod Nat 2012;2:186-99.

17. Ganjewala D, Mittal R, Gupta AK, Premlatha M, Dewar R. Antibacterial properties of lemongrass (Cymbopogon flexuosus Steud) wats essential oils in single form and combination of honey against drug resistant pathogenic bacteria. J Biol Active Prod Nat 2014;4:278-85.

18. Abe S, Sato Y, Inoue S, Ishibashi H, Maruyama N, Takizawa T, et al. Anti-Candida albicans activity of essential oils including lemongrass (Cymbopogon citratus) oil and its component, citral. Nihon Ishinkin Gakkai Zasshi 2003;44:285-91

19. López P, Sánchez C, Batlle R, Nerín C. Solid-and vapor-phase antimicrobial activities of six essential oils: Susceptibility of selected foodborne bacterial and fungal strains. J Agric Food Chem 2005;53:6939-46.

20. Fu Y, Zu Y, Chen L, Shi X, Wang Z, Sun S, et al. Antimicrobial activity of clove and rosemary essential oils alone and in combination. Phytother Res 2007;21:989-94.

21. Chaieb K, Zmantar T, Ksouri R, Hajlaoui H, Mahdouani K, Abdelly C, et al. Antioxidant properties of the essential oil of Eugenia caryophyllata and its antifungal activity against a large number of clinical Candida species. Mycoses 2007;50:403-6.

22. Mishra P, Mishra S. Study of antibacterial activity of Ocimum sanctum extract against Gram positive and Gram negative bacteria. Am J Food Technol 2011;6:336-41.

23. Hossain F, Follett P, Vu KD, Harich M, Salmieri S, Lacroix M. Evidence for synergist activity of plant-derived essential oils against fungal pathogens of food. Food Microbiol 2016;53:24-30.

24. Tyagi AK, Malik A. Liquid and vapour-phase antifungal activities of selected essential oils against Candida albicans: Microscopic observations and chemical characterization of Cymbopogon citratus. BMC Complement Altern Med 2010;10:65

25. Di Pasqua R, Betts G, Hoskins N, Edwards M, Ercolini D, Mauriello G, et al. Membrane toxicity of antimicrobial compounds from essential oils. J Agric Food Chem 2007;55:4863-70.

26. Burt S. Essential oils: Their antibacterial properties and potential applications in foods-a review. Int J Food Microbiol 2004;94:223-53.

27. Burt SA, Reinders RD. Antibacterial activity of selected plant essential oils against Escherichia coli O157:H7. Lett Appl Microbiol 2003;36:162-7.

28. Hyldgaard M, Mygind T, Meyer RL. Essential oils in food preservation: Mode of action, synergies, and interactions with food matrix components. Front Microbiol 2012;3:12.

29. Zinoviadou KG, Koutsoumanis KP, Biliaderis CG. Physico-chemical properties of whey protein isolate films containing oregano oil and their antimicrobial action against spoilage flora of fresh beef. Meat Sci 2009;82:338-45.

30. Cox SD, Mann CM, Markham JL, Bell HC, Gustafson JE, Warmington JR, et al. The mode of antimicrobial action of the essential oil of Melaleuca alternifolia (tea tree oil). J Appl Microbiol 2000;88:170-5. 